\begin{tabular}{l|l} 
DOI: $10.1515 / \mathrm{eec}-2015-0005$ & $\mid \begin{array}{l}\text { Eastern } \\
\text { European } \\
\text { Countryside }\end{array}$ \\
\hline $21^{\prime} 2015$
\end{tabular}

Slavomír Bucher, Štefánia Nováková

\title{
Territorial Aspects of Regional Identity and Respondents' Identification with the Region and Place: Case Study of Slovakia ${ }^{1}$
}

\begin{abstract}
The purpose of the study is to focus on the understanding of sense of place through the conceptualisation of regional identity. The theory of institutionalisation of regions, by geographers Chojnicki and Paasi, gives us a useful framework for understanding how regions and regional identity emerge, continually reproduce and, thus, transform in and through the practice of individuals and institutions at a variety of spatial levels. The submitted paper creates a compact mosaic of the selected theoretical approaches and chosen concepts of new regional, cultural and behavioural geography, which can be used in regional identity researches. The central purpose of the paper is to enrich and explain the possibilities of utilisation of behavioural techniques in the formation of regional identity and the identity of the area. The aim of the study is to identify the level of respondents' patriotism towards the selected hierarchical and residential regions of Slovakia.
\end{abstract}

Keywords: regional identity, sense of place, Slovakia, area, collective identities.

1 The paper is part of the grant research projects VEGA no. 1/0325/12. Intraurban structure dynamics in Slovakia in the first decade of the $21^{\text {st }}$ century and VEGA nr. 1/0165/15: Pro-poor tourism as a tool for sustainable development of marginalized communities and settlements in Eastern Slovakia 


\section{Introduction}

The aim of the article is to verify a hypothesis according to which residences in Slovakia represent an important stimulus of the local socioeconomic growth of the larger region. In the study, we mainly focus on the identification of the relationship between the collective identities of representatives of local elites, and the individual perception of regional identity, in relation to a hierarchical level of territory. In particular, the territory with specific social, economic or developmental conditions can be used as the basis for formation of territorial/local identity.

Consequently, we are dealing with the following research questions:

1. Collective identities will demonstrate the different scale of identification (sense of patriotism) within the various administrative units of Slovakia (NUTS 1-3, LAU 1,2).

2. What are the differences among self-governing regions according to the "intensity" and demonstration of regional identity? What is the role of a social, territorial and economical characteristic of a region?

3. What kinds of differences could be observed by comparing the urban/rural and immigrant/native respondents according to the 'intensity' and representation of regional identity?

This set of questions was selected on the basis of respondents' identification with various administrative units of Slovakia.

At the present time in Europe, the genesis of development of 'successful stories' is based on the usage of local resources as well as on the successful testing of general theories. Self-governing regions, declaring all-round development of the area and needs of inhabitants, have an important role in the local government of Slovakia. Self-governing regions guarantee the accomplishment of social, economic and cultural development of the area. This may cause discrepancies between the transfer of responsibilities among the particular municipalities (LAU 2) and self-governing regions (NUTS 3).

In Bucher's work (2012), respondents ${ }^{2}$ were asked questions about their social, cultural and economic references to municipalities (LAU2)

\footnotetext{
${ }^{2}$ Under the term of respondents we understand local deputies and municipal government representatives in our survey. Identical research was realised on the sample of
} 
and self-governing regions (NUTS 3). The scale and the place reference both represent a decisive role in the interaction of group identities. Collective identities are focusing mainly on issues and policy of various local administrative units (NUTS 1-3, LAU 1,2).

Regional/local identity is a phenomenon in which people identify themselves with the social system of a particular area, with its people, culture, traditions, landscape, etc. (Raagmaa, 1999, p. 10). It is generally agreed that the concept of regional identity is complex and hard to define. According to Paasi (2002, p. 807), the concept of regional identity is still unclear, although it has been an important component in the geographic subject for a long time.

Regions with arguably stronger regional identity show themselves to be more respectful and more willing to adapt to sustainable development principles. Thus, the distance-proximity perception to original and new residence plays an important role for various groups of residents of the area (urban/rural community).

\section{The theoretical Framework of Territorial Identity Formation and Identification of Respondents with the Region and Place}

The article is grounded in the Chojnicky concept (1996) that defined a region as a territorial social system. It differentiated four developmental stages of the region:

- Spatial crystallisation of the region (A)

- Development of regional awareness and identity (B)

- Institutional development of the region (C)

- Stability of the region (D)

A. Under the spatial crystallisation of the region, Chojnicki understands the nodal organisation of the municipal system, which is composed of urban centres that have subnational or lower-impact functions. Economic, political and cultural activities, which form a relatively closed unit, are

mayors of Czech municipalities by Chromý and Marada (2003-2004). Basically, our research verified results of Chromý and Marada's research, in which respondents (mayors of Czech municipalities) expressed the most positive attitude towards urban/rural municipalities (LAU 2) and towards the Czech Republic (NUTS 1). 
part of this area, whereas their spatial radius defines the boundaries of the region. The dynamics of this development is reflected in dialectical changes of the fundamental features of the economic region: its self-sufficiency and specialisation.

According to Chojnicki (1996), the key element of the spatial crystallisation of the region is the creation of boundaries. Boundaries are a necessary condition for the identification of the region as a special territorial unit.

B. The main elements of regional awareness and identity are opinions and views related to:

a) Idea and vision of the region

b) Assessment of the region

c) Symbolism of the region

The notion of the region in social awareness is the basis to convince people about the value and importance of the region. The notion begins with the fact that specific characteristics, in terms of economic, cultural and political life, are attributed to the region, with these attributes being positively rated by inhabitants of the region. Therefore, their inhabitants seek to preserve, strengthen, and develop them.

C. Institutional development of the region

We can distinguish two aspects of the institutional development of the region:

a) Institutional region facilities

b) The institutionalisation of the region as a unit of local subdivision

The institutional facilities of the region include all of those institutions that serve the population forming the regional community.

D. The stabilisation of the region (as its final phase of formation) does not affect the transformation and restructuring processes, which do not change the nature of the region. On the contrary, destabilisation is caused by processes that disintegrate the region by the weakening or destruction of its structures, which may lead to its disintegration. These processes include mainly deinstitutionalisation of the region, particularly the loss of the administrative function, processes of depopulation, and economic decline (Michaeli, Matlovič, Ištok et al., 2010; Matlovič, Matlovičová, 2005). 
[85]

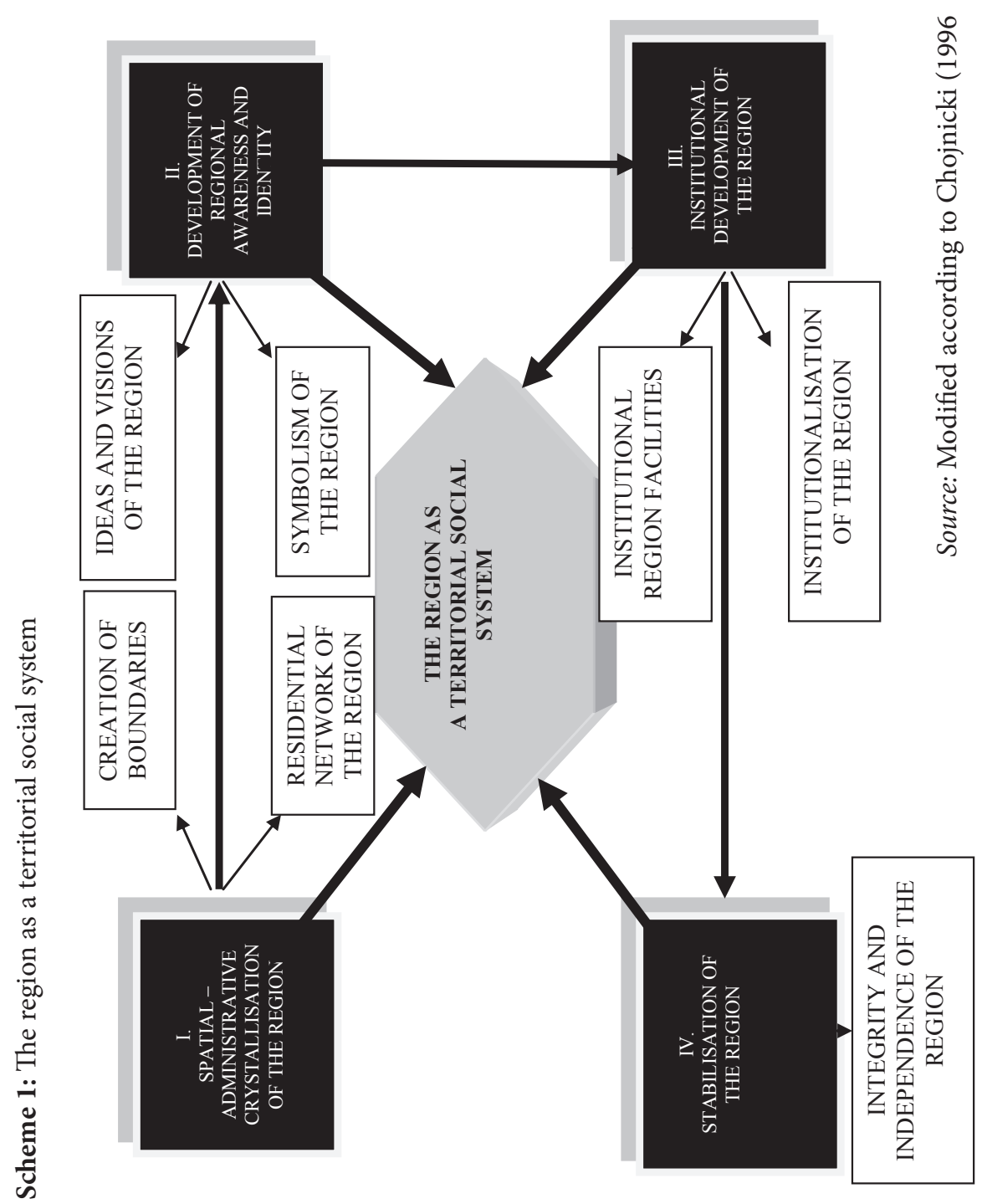


Authorities and specialists may have many ideas about the creation of the environment, compared to the way in which residents understand their surroundings. In practice, this difference means that regional identities cannot be seen as obvious-purpose, 'natural' qualities, but are viewed as socially constructed. Consequently, regional identities are dynamic. For example, the power balance between actors may shift, the feelings for a region may change, new actors can arrive in the region or new regional functions may be ascribed.

In our study, social identities are distinguished by their intention and subjectivity of the place and time. If we wanted to get back to the aspect essence, which is the goal of our research, then we would have to apply an individual approach to each respondent to understand his attitudes and thoughts. As a result, there would be four basic decompositions of social identities and their disproportions in space and time. This association would not be possible without mutual social interaction of all participants in society (Lefebvre, 1991, p. 62). Paasi (1986, p. 110) also deals with an aspect of social interaction, which is considered a fundamental element for forming regional awareness and collective identity of the place.

In the broadest sense, the definition of territorial identity is up to the citizens themselves, to other residents, as well as to the environment that surrounds them (which is understood in different hierarchical, semantic and structural contexts).

The formation of civil society has incorporated developmental reversal in its substance. Harmonisation of growth of any territorial unit (municipality, local region, Central European macro-region) is connected to the reversal activity of the forces of territorial identity. This turnover is extremely important and valuable for society.

A neighbourhood (propinquity) factor between the various communities plays an important role in the process of transformation of spatial identification. The essence of local identity lies in the substantial relationship of people in the area. This affinity to the place has been shaped in the historical process of region crystallisation, which contributed to the transformation of its power structures, whereby everyday relations, constituted by the endogenous area's potential ("bottom-up"), were superior to the bureaucratic machinery of the institutional apparatus of the state.

The significant process of identification is based on the mapping of the circumstances connected to individual actions. The origin of the word 
"identity" rests in the universality and individuality, as it concerns a set of qualitative and quantitative characters of a territory and group.

As authors Keating (2001, p. 45), Relph (1976, p. 102), and Murphy (1991, p. 25) emphasised, an important key to understanding the links between society and the region is the historical concept of area formation, which is based on the regional identity and emotional relationship of natives to their hometown.

\section{Methodology}

When choosing the appropriate questions for our survey, we were inspired by various works that have been focused on national and cultural identity, national pride, and the establishment of collective identity with many local administrative units and cultural groups. Adapted inquiries to our questionnaire were inspired by essays of Vondrušková (2000, p. 56), Zemánek (2003, p. 130), and Heřmanová (2008, p. 203), as well as by the theoretical and methodological concept of institutionalisation of the region by Lagendijk and Cornford (2000, p. 56). Piscová (1996, p. 47) highlighted the complexity and the complicacy of the national identity, whereas, currently, many aspects of this problem are subjects of radical changes, particularly the roles (and understanding) of ethnicity, culture, globalisation and nationalism. On the basis of the consequences of particular inquiry sources on the survey, we will try to formulate necessary hypotheses that will validate the reliability of the data, i.e. unconfirmed data by a comparison of our figures with a credible publication output of other scholars.

The place for confrontation of outlining the hypothesis is given in the analysis.

Working hypotheses:

- Hypothesis 1: Collective identities will manifest a different scale of identification (sense of patriotism) with various self-governing regions.

- Hypothesis 2: According to Paasi's phenomenological theory of institutionalisation of the region, taking into account Chojnicki's developmental stages of the region as a territorial social order, we beg to claim that the self-governing regions will not represent the territory to which respondents will display the highest level of fellowship (patriotism). 
The essential aspiration of the study is the compilation of questions that would point out the identification of respondents with the region and place.

The relevance of our results (on the sample of representatives of local deputies) is also confirmed by research realised by Bodnárová (1997, p. 21). The fundamental file of her research was represented by Slovak inhabitants at the age of 18 (number of inhabitants over the age of 18 was 3,794,000). The sample file consisted of 1500 respondents. Our results virtually verify Bodnárovás research, in which respondents expressed a positive attitude towards the two territorial levels of territorial and administrative division of Slovakia.

The fundamental prerequisite of this research was the questionnaire assembly dealing with respondents' identification with the region, place and social groups, as well as respondents' self-reflection regarding the cultural-historical potential of the specific region. The writing-up of data gathered during the survey with the working title of "Identity of Slovak regions" was realised from May 15, 2011 until September 15, 2011. The target group consisted of local deputies who had been elected to parish, municipal and local councils in 2010, and the exact number of aldermen was 21,020 (Statistical Office of the Slovak Republic, Election Statistics section, November 28, 2010).

While it would not have been possible to realise personal surveys using the PAPI ("paper and pencil") method with such an extensive ensemble of respondents, we decided to apply a less complicated form of the online questionnaire. Therefore, another indispensable factor for functional categorisation was the availability of addresses' validity of local deputies. To these email addresses, published on municipal and city websites and provided by local (parish) councils, we sent 9547 online questionnaires. We obtained responses from 2114 local deputies (22.1\%).

With regard to ongoing modernisation and acquisition of new political, socio-cultural and economic models of life, there is a regression of tradition, customs and norms in Slovak society, which have been dominating in society for the last decades. Respondents' connection to the place and their patriotism were verified via the following questions (in their questionnaire order):

1. Would you like to live in the same rural/urban area you are living (at the present time) also in the future? (A) Yes, I would like to live in 
the same rural/urban area where I am living (at the present time) also in the future; (B) No, I would not like to live in the same rural/ urban area in the future.

2. Can you identify a certain place (city or municipality) in Slovakia which you recognise as your home? Answers: yes or no.

3. Can you identify a certain place (city or municipality) in Slovakia with which you have a really close relationship and which you do perceive as your birthplace? (A) Yes, it is my place of residence; (B) Yes, but it is not my place of residence; $(\mathrm{C})$ No.

The next question identifies respondents' relationship with particular territorial units according to the distribution of responses, which were associated with the sense of patriotism towards the rural/urban area, district, region, Slovak republic, and the European Union. The wording of the question is as follows: Put in order your sense of patriotism, from 1 point (strong feelings) to 5 points (weak feelings), i.e. Primarily, I am an inhabitant of: (A) the rural/urban area, (B) the district, (C) the county, (D) Slovakia, (E) the European Union.

Slovakia is a unitary state composed of municipalities (obce), cities (mestá), and self-governing regions (samosprávne kraje). The local level of governance represents 2792 municipalities (obce) and 138 cities (mestá) in Slovakia.

Municipalities (LAU 2) may perform certain duties in right of the state, concerning register offices, construction permits, and some aspects relative to education, though the state remains responsible for the quality and funding of such duties. Their competences include participation in regional planning, culture and sports activities, health, social assistance, pre-school and primary school, housing, local development, sewage and municipal waste, water supply, the environment, public transport, and road maintenance.

The local council (municipalities: obecné zastupitelstvo, cities: mestské zastupitelstvo) is the local authority's deliberative entity and it is composed of members who were elected by direct universal suffrage for a period of four years.

The regional level of governance represents eight self-governing regions (NUTS 3). Self-governing regions may perform certain duties in the name of the state, mainly regarding education, healthcare and transport. Their competences include regional road networks, land development, regional 
[90]

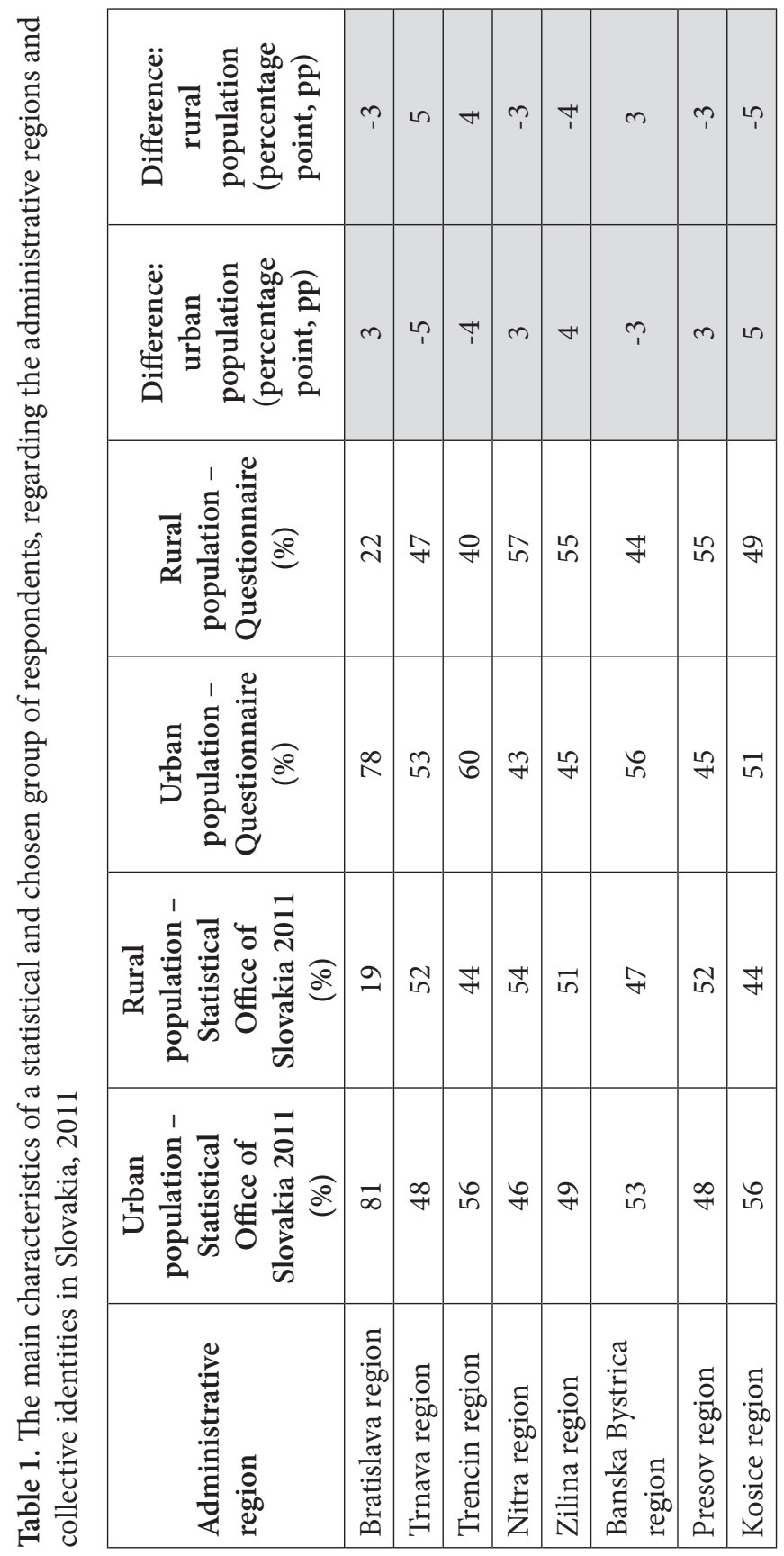




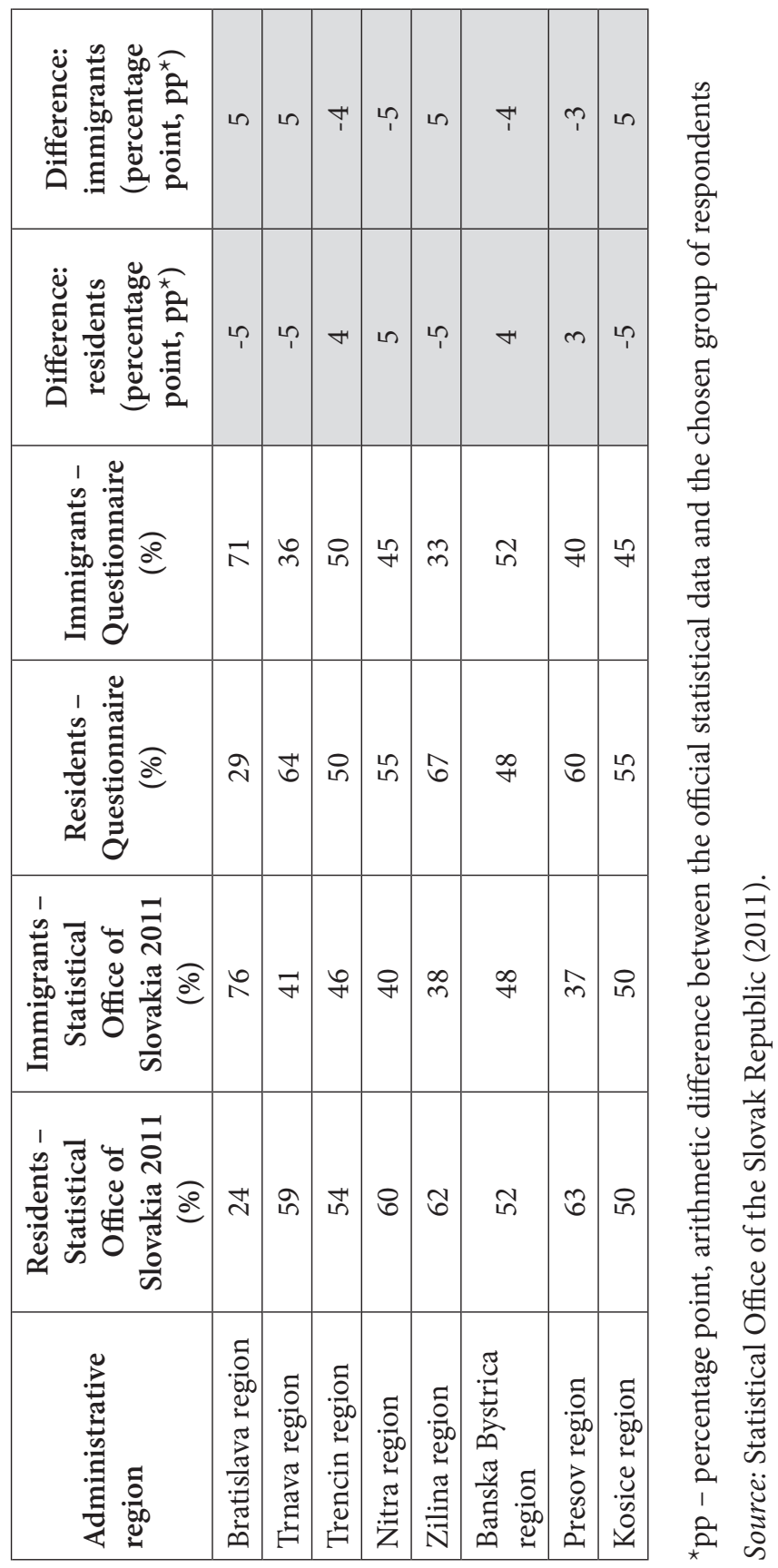


development, secondary education, hospitals, social services, culture, participation in civil defence, and licences for pharmacies and private physicians.

The regional council (zastupitel'stvo samosprávneho kraja) is the region's legislative and decision-making entity and it is composed of members elected by direct universal suffrage for a four-year term.

In our research work, we divided respondents into four basic categories, according to the relation to the current residence, i.e. rural population, urban population, natives and immigrants.

In our research, we used a standard scoring method, in which the former values of selected respondents were normalised or quantified into a dimensionless quantity. At first we calculated the arithmetic mean $\left(\mathrm{x}_{\mathrm{i}}\right)$ and standard deviation $\left(\mathrm{sx}_{\mathrm{i}}\right)$ of each indicator. From the initial values, we subtracted the arithmetic mean. We divided its variance by the standard deviation. Then we defined the evaluation criteria for the resulting sequence (from 0 until 100). The higher value is attributed to the region that defines acceptance of a given phenomenon.

\section{Results}

\section{Social identification of respondents with place}

With regard to ongoing modernisation and acquisition of new political, socio-cultural and economic models of life, in Slovak society there can be observed a regression of tradition, customs and norms, which have been dominating in society for the last decades. Within identity research in Slovak society, a model based on the empirical study of territorial identity is sketched.

Respondents expressed their fellow feeling to the current place of residence by answering the following question: Would you like to live in the same rural/urban area you are living (at the present time) also in the future? Possible answers: yes or no. Respondents can identify not only with the region but also with its social content, i.e. cultural and historic potential. Through their daily activities and interactions with the social conditions of the region, respondents create an image and mental map of the area in which they live. The result of this process is the establishment of regional identity of the individual. 


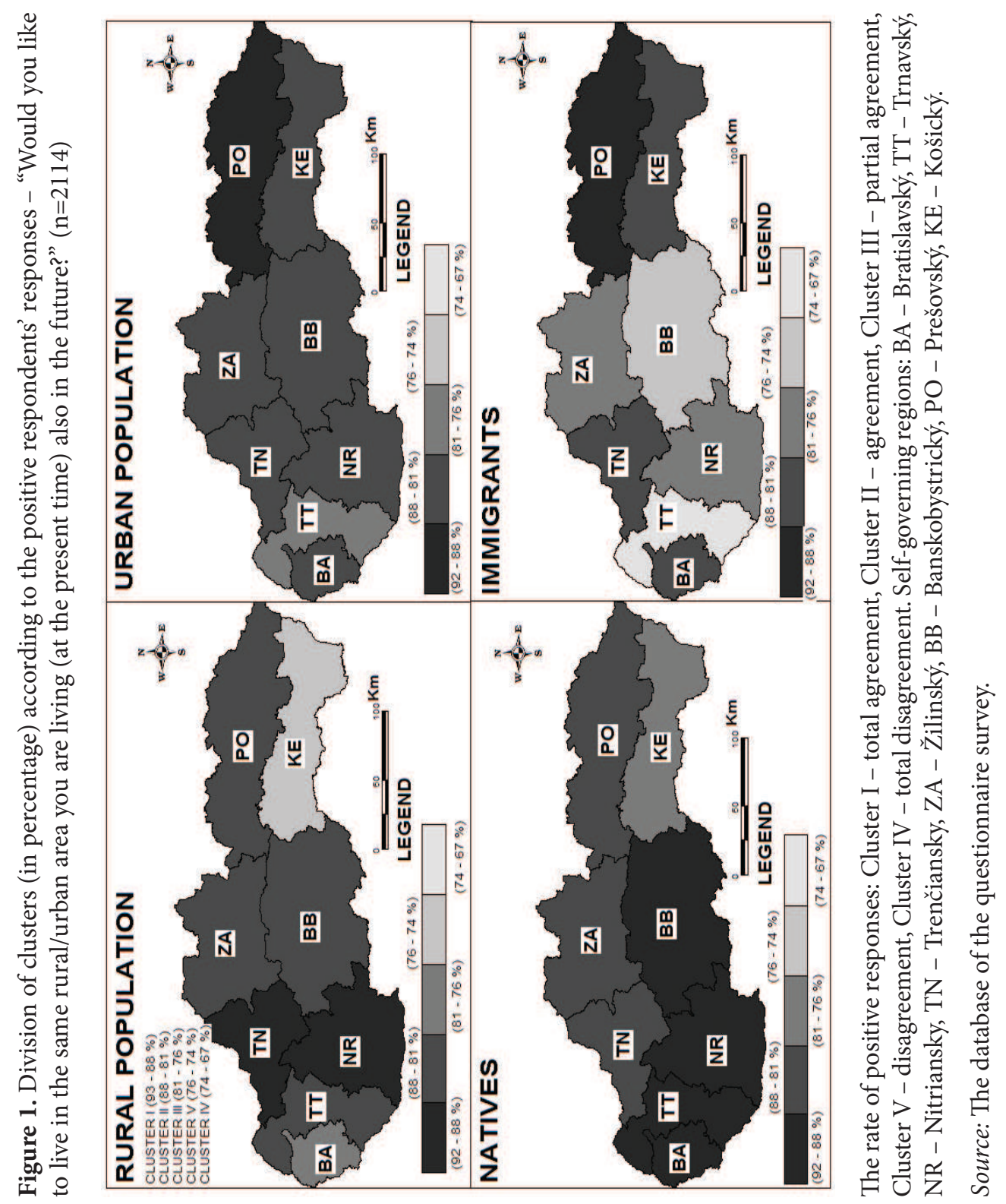


The highest rank of non-identification with its current residence is in a group of immigrants. Figure 1 presents the results of attitudes of different groups of people in their current residence.

In respect to the other comparison of collective identity, the results show that the natives are not really identified with the opportunity to leave, respectively, and to abandon their current place of residence in relation to other comparable collective identity.

On the other hand, a question arises: whether immigrants were able to find the internal sense of security and harmony in a new environment. Who would not desire a satisfied life, for material safety and for the feeling of safety and comfort in many life situations? If they had not reached the stated conditions in their native place, and have not even found it in their new home, it is highly probable that they would re-migrate or, respectively, we could find negative feedback between them and regions.

In the following question, respondents were asked to clarify whether they recognise the rural/urban area they are living in as their home. Possible answers: yes or no.

Through this question, the respondent shall immediately identify with the economic, cultural and social subsystem of the region, which, as a consequence, tends to the development of regional knowledge and stabilisation of the local identity of the place. The highest number of respondents who have not identified with the place (that they consider as their home) was expressed by the group of immigrants. As mentioned above, the immigrants, in particular, demonstrate the lowest sense of local patriotism, as well as identification with the new region. Social features and processes are part of the collective concept of a memory of the place. The immigrants do not express a positive association with the current region, the result of which is a gradual slackness of their territorial identity in comparison to the natives. It is indirectly reflected in a lower intensity of collective memory, because the reconstruction of the past through the use of experience, events and impressions of collective identity of immigrants is lacking, mainly in relation to the current place of residence (Figure 2).

The last question, which was concerned with the cultural identification of respondents with the place, reflected the recognition of the presence of the rural/urban area that respondents considered to be their birthplace. The question is as follows: Is there any rural/urban area in Slovakia with which you hold a close relationship, and which you perceive as your birthplace? 


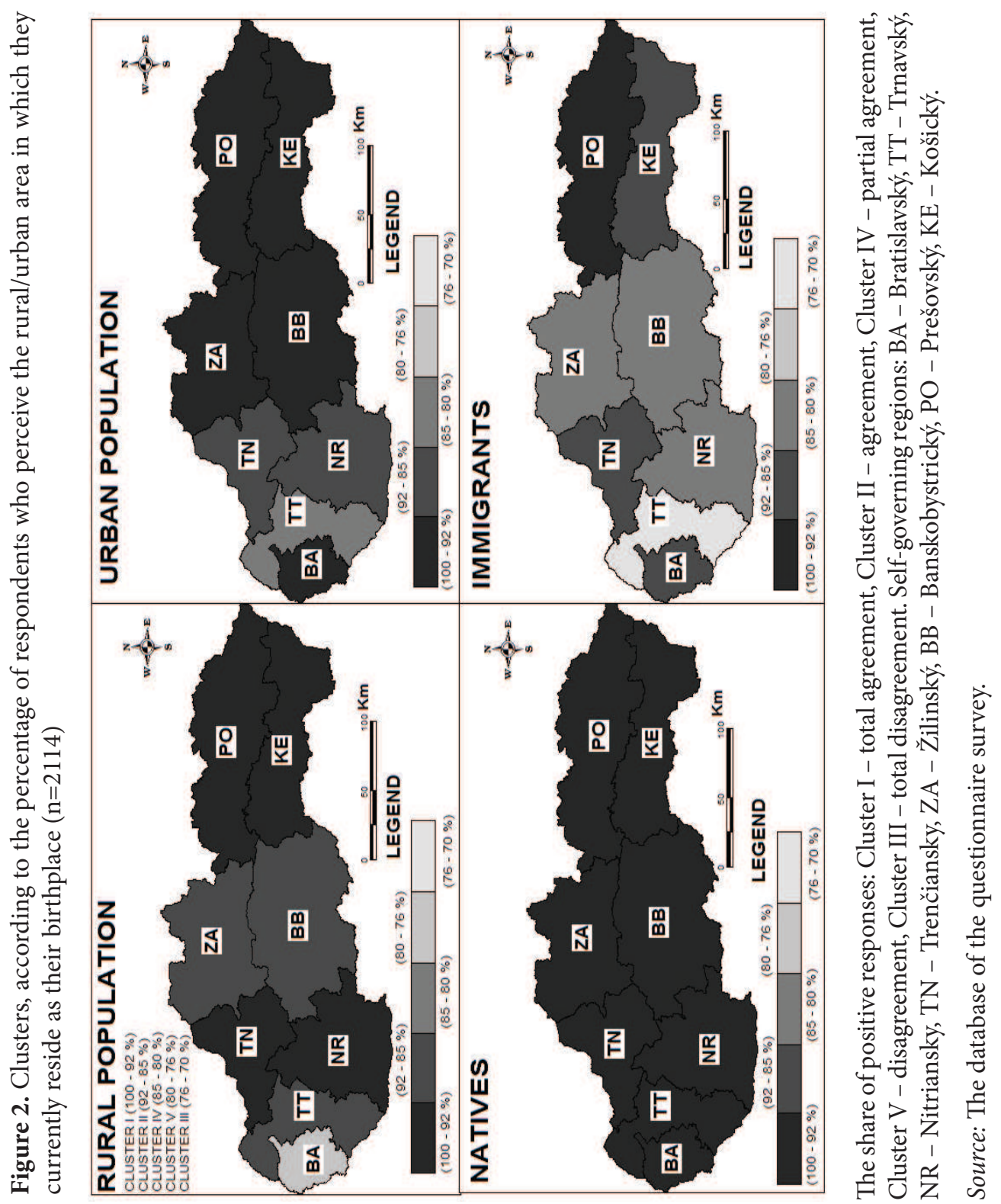


Respondents could choose one of three options: (1) yes, it is identical to the current residence, (2) yes, but not identical to the current residence, (3) no, there is no rural/urban area in Slovakia with which I have a close relationship, and which I perceive as my birthplace.

This question relates to the previous one, wherein it describes the social aspect of regional identity. Internal differentiation of regional identification expresses the phenomenon of coexistence of permanent and temporary residents of the region. Offered answers demonstrate the self-identification with the region or the place in which respondents live or would like to live, on the contrary to the place where they do not feel comfortable and safe.

The fundamental prerequisite of the recognition of a birthplace concerns family relationships, besides a variety of social, technical and economic infrastructure as well.

Referring to Zich (2003, p. 43), the family is the determining identification part of local identity. The family represents the closest cultural conditions, and the understanding of home is derived from the family. Nothing but a place has always been determined (e.g. quality environment). Home is where the family is.

The highest proportion of respondents who are identified with their rural/ urban area as their birthplace reach collective identity of the autochthonous population. As you can see in Figure 3, cluster I shows the highest rates of residence identification with the birthplace in recognised collective identity of natives. On the other hand, the lowest proportion of acceptance of residence as the birthplace confirms the identity of immigrants. The collective identity of respondents who did not identify with the phrase "residence - birthplace" shows clusters II and III.

\section{Respondents' awareness and patriotism in connection to the various hierarchical territorial administrative units}

The subhead identifies respondents' relationship to particular territorial units according to the distribution of responses that were associated with the sense of patriotism towards the rural/urban area, district, region, Slovak Republic, and the European Union. The wording of the question is as follows: Put in order your sense of patriotism, from 1 point (strong feelings) to 5 points (weak feelings), i.e. Primarily, I am an inhabitant of: 


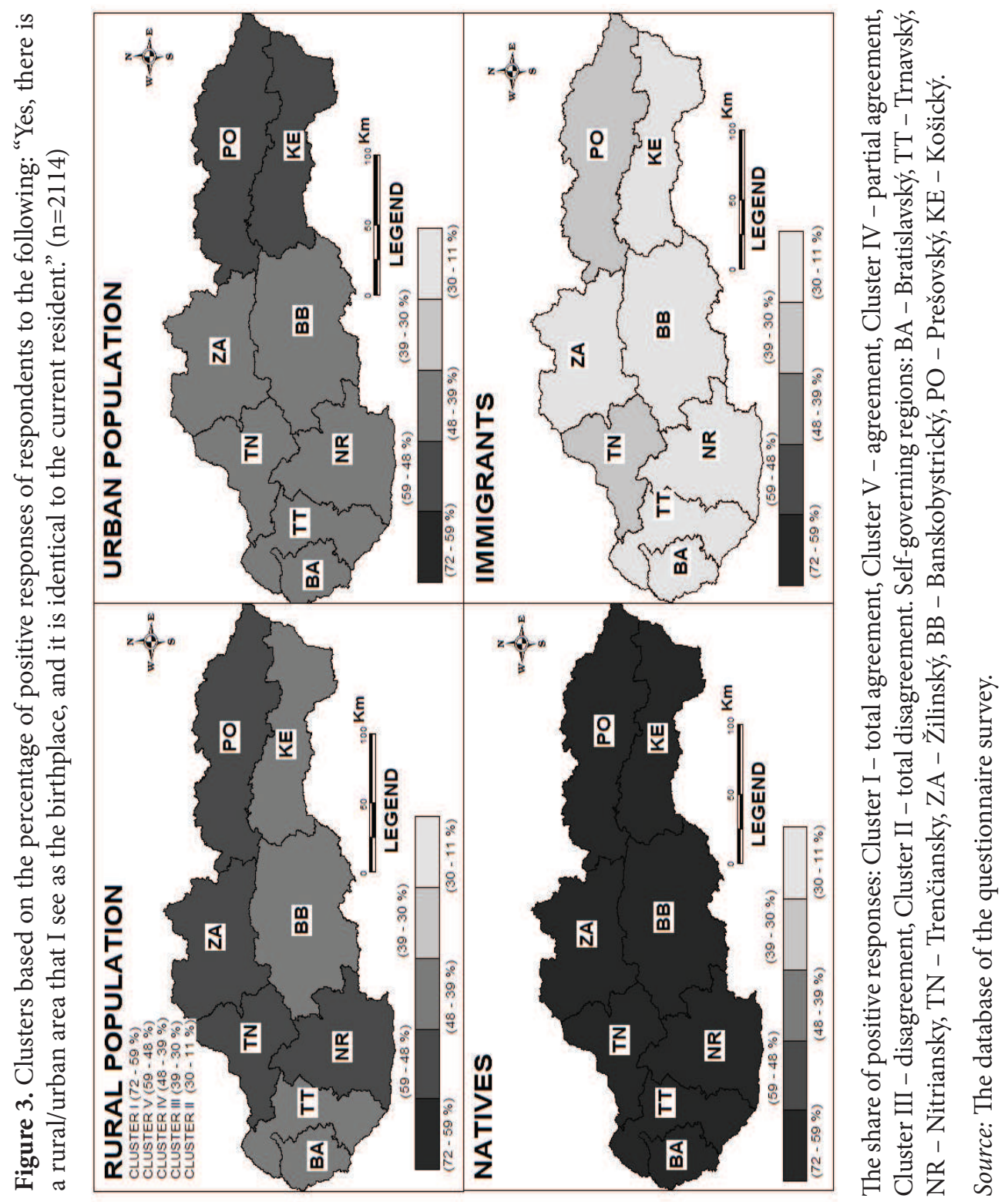


(A) the rural/urban area, (B) the district, (C) the county, (D) Slovakia, (E) the European Union.

The position indicates the importance of the answer. On top of the scale is semantically the most significant response (in our example, the rural/ urban area). These points are the sum of all responses to this question. Respondents showed the highest level of patriotism towards the territory with the lowest number of points. On the contrary, the highest number of points gained the territorial unit to which respondents showed no sympathy. The final results for the whole of Slovakia point out the achieved scores in relation to the various geographic units: the rural/urban area (4031 points), Slovakia (5315 points), district (6368 points), county (7208 points), the European Union (8590 points).

Respondents expressed the highest level of sympathy at the local level, specifically towards the rural/urban area. As can be seen in Figure 4, very strong feelings in the rural/urban area can be observed in responses of natives and rural communities. A positive attitude (very strong feelings) towards the rural/urban area is expressed at the national level by $61.5 \%$ of natives and $60.4 \%$ of the rural population.

Figure 4. Collective identities and their patriotism relationship to the Local Administrative Units (LAU 2) in Slovakia ( $\mathrm{n}=2114)$.

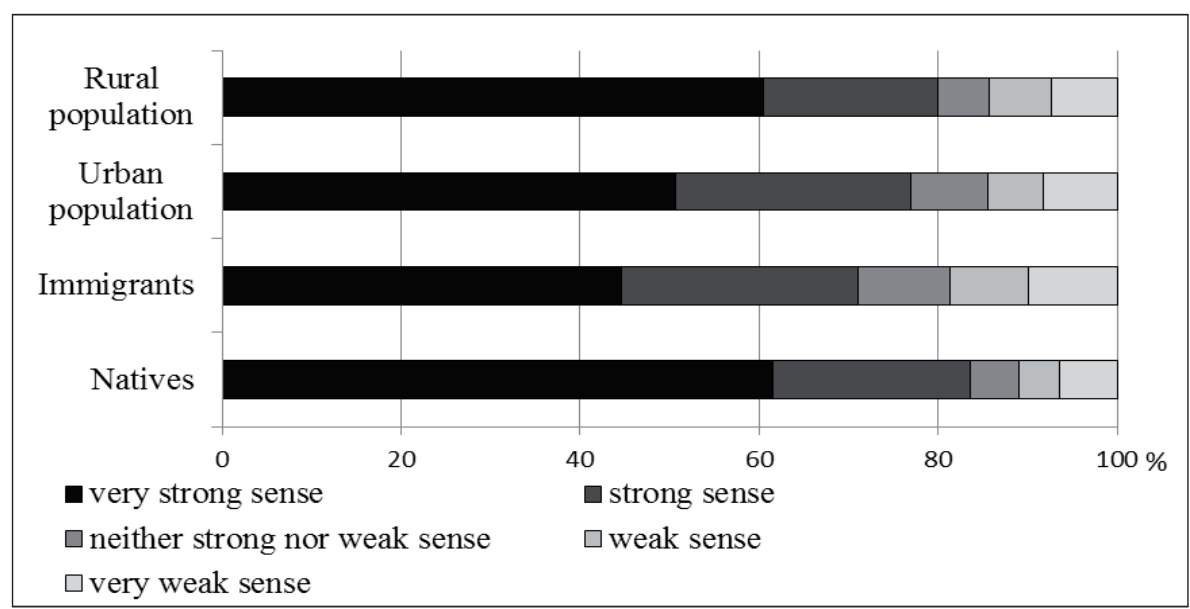

Source: The database of the questionnaire survey. 
The collective identity of immigrants (44.6\%) declared quite opposing attitudes for the current residence. At the level of self-government regions, the proximity to the residence is differentiated by the type of residence (rural/ urban) and the time spent in the current residence (natives/immigrants). It has been shown that respondents have been living in the place of permanent residence since their birth, and rural populations have shown very strong and strong feelings for their permanent residence respectively.

In our survey, we would like to highlight the correlation between patriotism towards different territorial units and the interests of the respondents in understanding the current problems, respectively the economic and political situation in the region.

Social contact in the quarter of the rural/urban area is implemented in a relatively small area. Relatively bounded space, with an occurrence of formal and informal connections, creates a fellow feeling and, thus, inhabitants can create a close connection to the place.

The Slovak Republic presents the second hierarchical group to which respondents expressed their sympathy: patriotism. The diversity of religious and ethnic composition, as well as the perception of the state, has affected the level of patriotism, which is understood by collective identity of the population. Once again, we can see the difference in the relation to the territory by a vertical cross-section of collective identities at the perception level: natives-immigrants, urban-rural population. At the national level, the highest value reached (very strong feelings of belonging and patriotism in Slovakia) immigrants (38.6\%) and the urban population (35.0\%), in contrast to the natives (26.9\%) and the rural population (26.7\%). The individual differences between collective identities are shown in Figure 5.

A representative sample of respondents - in our case, members of the parish, municipal and local councils - significantly affects the actual results of the study.

With the sufficient distance from local (the rural/urban area) and national (the state) patriotism, we can detect the elements of transnational and European identification of respondents. Abreast of collective identities, there is a noticeable identification with "European patriotism" at the observed level in Slovakian immigrants (11\% of respondents have a very strong sense of patriotism towards a united Europe) and the urban population $(9.6 \%)$. 
Figure 5. Collective identities and their patriotism relationship to Slovakia $(\mathrm{n}=2114)$

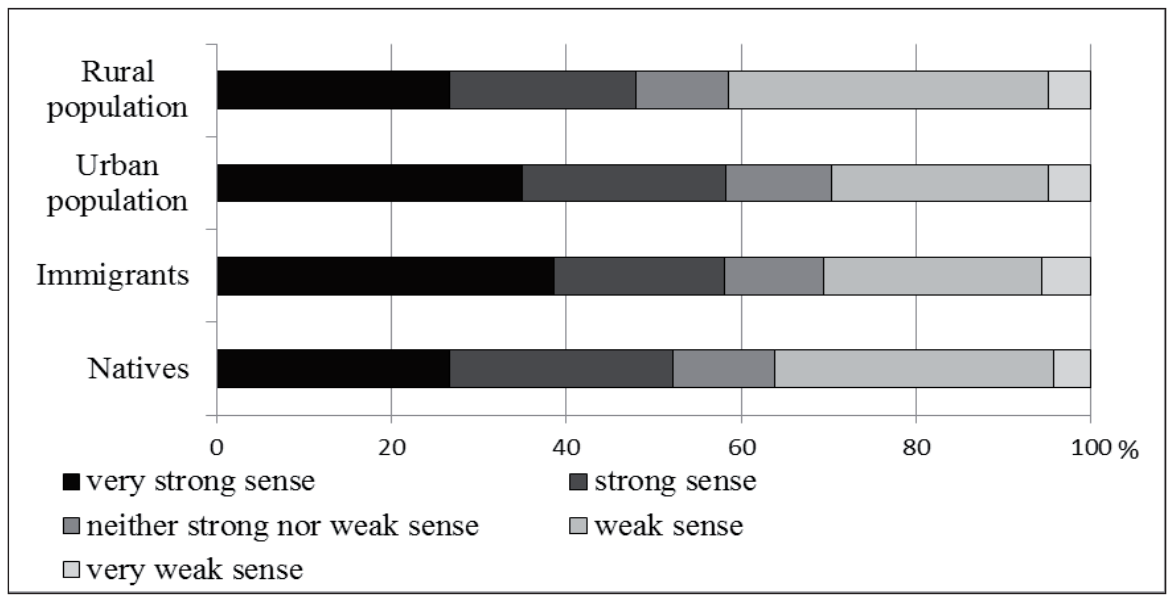

Source: The database of the questionnaire survey.

Within all four collective identities, the Bratislava region and Nitra region (taking into account the very strong, strong and medium sense of respondents of a united Europe) act as the most ideal places for culturally heterogeneous and pluralistic Europe. In the case of the Nitra region, "the European patriotism" is affected by the marginal position of the Hungarian minority, which does not identify itself with the Slovak nationality. The Hungarian minority sees the maintenance of individual identity, language, culture and tradition in a united Europe - Europe's regions and crossborder cooperation. Respondents of the most advanced region in Slovakia are able to imagine a link of national interests with European values. Attractiveness of the geographic location, economic background, as well as the localisation of multinational corporations, institutions and the political system of the country predetermine the Bratislava region for closer cross-border and international cooperation (e.g. New Golden Triangle: Bratislava-Vienna-Brno), which will be reflected in the swiftness recognition of European standards and values (Figure 6).

In the case of respondents from the Bratislava region, identification through personal experience can be a key aspect of identification with European identity - the personal contact with "Europe" (travelling, 
Figure 6. Collective identities and their patriotism relationship to the EU in Slovakia $(n=2114)$

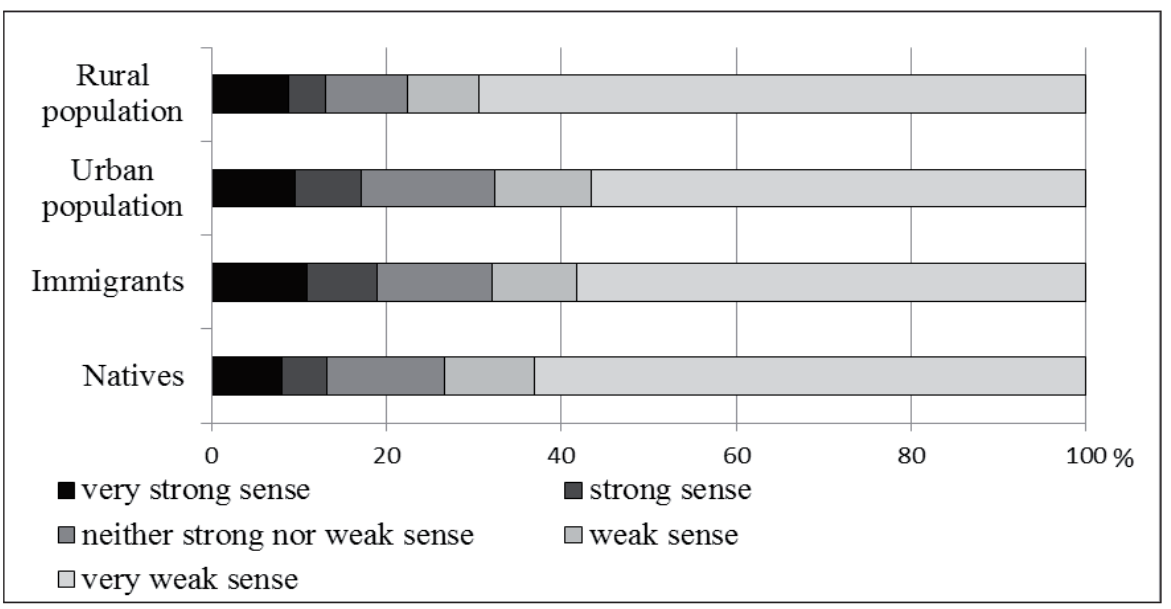

Source: The database of the questionnaire survey.

Figure 7. Collective identities and their patriotism relationship towards the selfgovernment regions - NUTS 3 in Slovakia $(n=2114)$

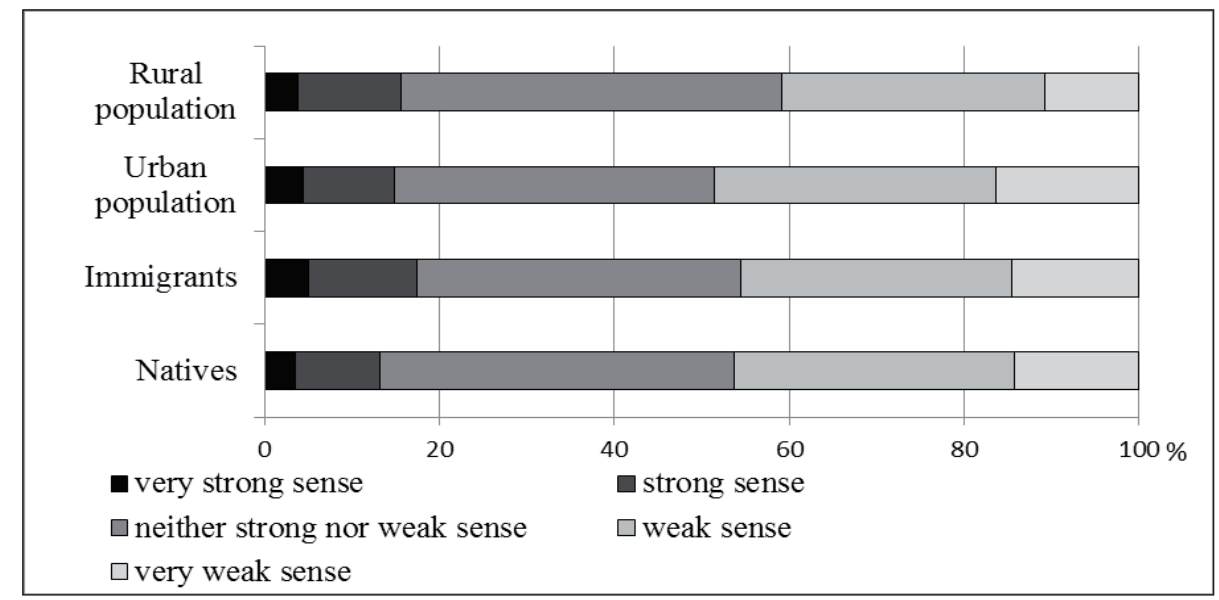

Source: The database of the questionnaire survey. 
working, studying, languages) and our personal sense of unity (reflection of Europe as a home).

We observe low values symbolising the affection of respondents towards the self-governing region on all collective identities of respondents (Figure 7).

A very strong sense of patriotism from all territorial units was recorded in the lowest territorial administrative unit: the rural/urban area. Almost $55 \%$ of respondents in Slovakia identified the rural/urban area as a territory to which they show the highest sympathy, followed by the Slovak Republic (32.2\%), united Europe (9.4\%), region (4.3\%), and district (4.0\%). Individual results confirm hypothesis 1 , which deals with the varying degree of identification (sense of patriotism) of collective identities with different territorial administrative units (Figure 8).

Figure 8. I feel myself above all the inhabitants of ... $(n=2114)$

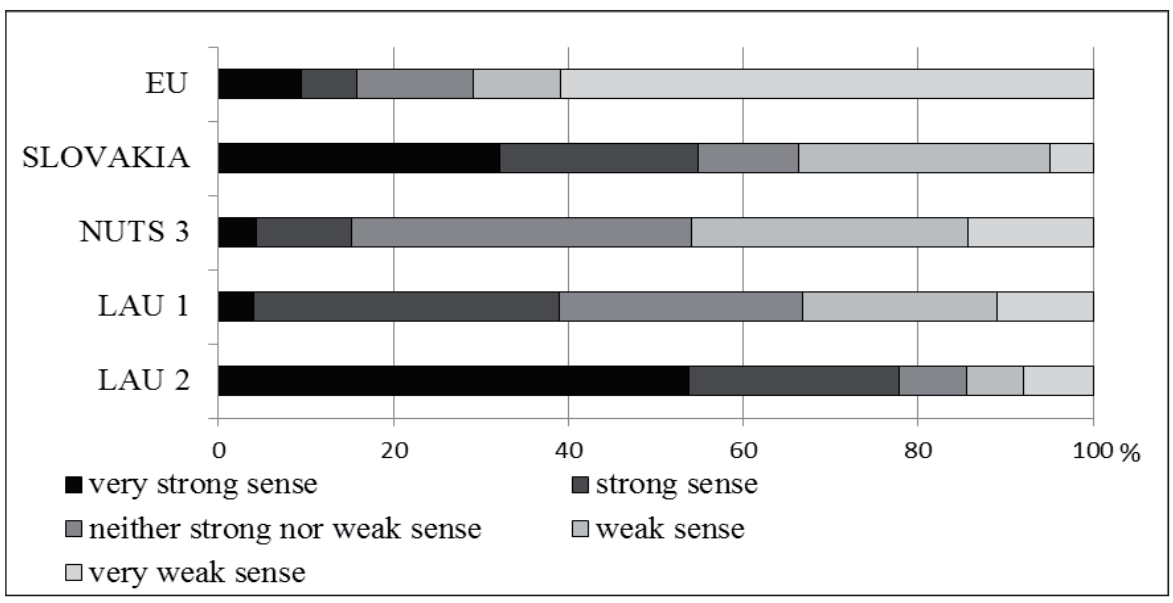

Source: The database of the questionnaire survey.

\section{Discussions}

Processes of formation, decomposition and re-reconstruction of the region, which were described in essays of Paasi (1986, p. 115), Lefebvre (1991, p. 205), and Maskell and Malmberg (1996, p. 34), were not used in the circumstances of self-governing regions in Slovakia. Contemporary 
territorial and administrative division of Slovakia came into force in 1996, for the purposes of the determination of the territorial and state administration at the regional level, with law No. 221/1996. According to Slavík (2001, p. 38) and Sloboda and Dostál (2005, p. 11), eight current regions do not respect the existing development criterion, natural and geographical boundaries, as well as the spatial sphere of the historical regions.

If we strictly followed the stages of the regional development, based on the phenomenological concept of Paasi (1986, p. 120; 1991, p. 247; 2003, p. 198), and we took into account the model theoretical basis of region formation as a territorial social system by Chojnicky (1996, p. 13), we would come to the conclusion that the (former) districts (Figure 8) and the self-governing regions are artificial territorial administrative units, which were "imposed" by the central government upon the population without any constructive discussion between the public and experts on the topic.

Based on the analysis of respondents' patriotism towards the territory, we can observe that self-governing regions (NUTS 3) do not carry the development of local culture and innovation. Respondents in our survey confirmed the highest degree of patriotism towards Slovakia and the urban/ rural municipalities (LAU 2) in which they live.

As Paasi (1986) noticed, the institutionalisation of the region is the socio-spatial process that has formed a spatial unit as part of a spatial structure of society. It becomes visible and clearly identifiable in various spheres of social practice and social awareness.

Self-governing regions have not reached the last phase - "the stabilisation of the region" - because their boundaries, jurisdiction and responsibilities were artificially created and approved by parliament, without constructive discussions with the local population.

Suburban areas or their attraction zone should be the impulse in the development of regional and local autonomy. An attraction zone of towns would ensure the development of local and regional infrastructure and competitiveness of the region itself. The competitiveness of the suburban areas and the rise of the quality of living can be reached by:

- The technical infrastructure of the area, the cultural infrastructure, and the regeneration of settlements and residential and nonresidential premises.

- Tourism, (extent of) small and medium enterprises (development), and promotion of innovation. 
- The development of culture and cultural heritage.

- The sustainable development and creation of a knowledge society.

Our results pointed out the contemporary micro-regionalism with greater autonomy (self-rule) in decision making and, thus, more effective protection of distinctive cultural features and greater democracy through enhanced capacity of communities to choose the form of government which represents them. It is necessary to build up regionalism between local communities and to strengthen the common sense of their local identity.

The result of regionalism is the idea that a region becomes more economically integrated and it will necessarily become politically integrated as well. The increasing autonomists, the micro-regionalisation of Europe promoting cultural diversity, and the involvement of subnational actors in the EU decision-making process raise the possibility of the emergence of an inward-looking, competitive and culturally protectionist bloc (Longo, 2003, p. 479).

Several examples of the bottom-up approach towards Local Economic Development:

- Balances local interests towards sustainable development

- Demands interaction among social, public and private sectors

- Makes the best of available local and external resources with a longterm perspective

- Understanding thoroughly the local circumstances and characteristics (e.g. social, economic, geographical, political) is a prerequisite to successfully combining bottom-up LED tools with complementary traditional ones.

On the other hand, there is an integration process of the EU and an integrated approach, which will provide an opportunity to increase the effectiveness and the quality of the delivery of cohesion policy. The integrated approach has also worked well in the urban context, and shows how European cohesion policy has helped to promote integrated urban development.

Partial results of the research could be a case study of the wider region and they could provide valuable information about the local self-government in a united Europe. The impulse for the development of the EU should be in local communities, which would take part in building democracy and sustainable development of the region and its inhabitants. 
In this regard, the future shape of Europe should be formed by increasing the active approach of local and regional authorities, by exchanging experience at the local and regional level, and through cooperation with partners from all over the world.

Activities of local governments in the EU and around the world should reflect daily needs of their inhabitants (e.g. in regional policy, transport, the environment, equal opportunities, social affairs, employment, energy, public services). These fundamental activities should be coordinated through local political groups and committees in order to be involved in EU legislative proposals, and should be overseeing the interests of local and regional self-government contained in legislative proposals in the early stages of the EU legislative process. These fundamental activities should be coordinated through local political groups and councils, which would influence EU legislative proposals and would control/ensure that the interests of local and regional self-government were contained/included in legislative proposals in the early stages of the EU legislative process.

\section{Conclusion}

The main goal of this essay was to analyse the relationship of collective identities with the individual territorial level. First and foremost, we focused on the respondents' relationship to municipalities, represented by the rural/urban area in which respondents are living. We have clarified that respondents, such as the autochthonous population, immigrants, and rural and urban populations, have an influence on the formation of a relation to the place of living.

From the perspective of a closer relation to the Slovak Republic, we found it useful that a close relation was also expressed by respondents who claimed that they were ashamed of some factors in Slovakia; moreover, they totally disagreed with the fact that Slovakia is a better country in which to stay than many others. According to what was mentioned above, we can also conclude that the relation to the Slovak Republic means the relation to the values that connect people who are living in this area.

Relatively, a new self-government region is still unable to establish itself in the memory of respondents, which is an essential construct of regional identity of the place. 
The difference in the scale significantly affects the preferential behaviour of collective identities. Respondents demonstrate a higher rate of selfidentification with the lowest territorial administrative units in Slovakia, due to cultural, territorial and economic ties to their residence.

The primary hypothesis stated that there are large variations in the intensity level of respondents' patriotism of collective identities among the different levels of administrative division. Patriotism is given by the different level of their natural formation in terms of traditional spatial knowledge that is based on the cohesion with the historical regions.

In comparison with rural communities (LAU2), self-government regions (NUTS 3) show the lower degree of patriotism. Here are the following reasons:

- In spite of the fact that self-government regions (NUTS 3) have defined boundaries, they are not accepted in social awareness of the respondents.

- Even though the self-government region (NUTS 3) as an autonomous territorial unit has its symbols (state coat of arms, flag, anthem), a number of our respondents could define the symbol of their urban/rural community, in contrast to the region's symbol.

- In daily activities, respondents are frequently using the services of local institutions (schools, media, authorities, hobby groups) in towns and rural municipalities (LAU 2). Since the respondents are not in contact with the institutions of the region (NUTS 3), they could not clearly define what types of economic, cultural, eventually info-educational services they can provide.

- Finally, we can say that self-government regions could not establish their position in the regional spatial structures and in the minds of respondents (local deputies and municipal governments represented in our survey).

The results of our research can offer useful suggestions to establish democracy and sustainable development of micro-regions, not only in Slovakia but also in the EU. They can also offer the idea of how to normalise relations between local government and citizens through the utilisation of local policy.

- To support the building of democratic local governments in all of Europe. 
- To support the cohesion and unity among members of municipal and local governments of EU Member States.

- To provide key information related to local governments.

- To promote social, economic and cultural development and environmental development as well as public services provided by "good local governance" (based on the theory of good governance) of the sustainable and local social inclusion.

\section{References}

Bucher, S. (2012), Samosprávne kraje na Slovensku - formovanie identity a inštitucionalizácia $v$ kontexte integrácie do Európy regiónov [Self-governing regions in Slovakia - Identity formation and institutionalization in the context of integration to the Europe of regions]. Prešov: Dizertačná práca, pp. 225.

Heřmanová, E. (2008), Vykořeněné a nevykořeneněné obce (na př́kladu vbraných obcí Tachovska a Domažlicka) [Uprooted and not-uprooted villages (presented on the example of selected villages in the Tachov and Domažlice regions)], in: Šimunek, R. (ed.), Regiony - časoprostorové průsečíky? [Regions like the spatial and temporal points of intersection?] Monografie ze stejnojmenné konference konané 23. 1. 2008. Praha: Historický ústav AVČR, pp. 193-213.

Chojnicki, Z. (1996), 'Region w ujęciu geograficzno-systemowym' ['Region in the terms of geographical system'], in: Czyź, T. (ed.), Podstawy regionalizacji geograficznej [Basis of geographical regionalization], Poznań: Bogucki Wydawnictwo Naukowe, pp. 7-43.

Keating, M. (2001), 'Rethinking the region. Culture, institutions and economic development in Catalonia and Galicia', European Urban and Regional Studies, vol. 8, pp. 34-217.

Lagendijk, A. and Cornford, J. (2000), 'Regional institutions and knowledgetracking: New forms of regional development policy', Geoforum, vol. 31, pp. 18-209.

Lefebvre, H. (1991), The Production of Space. Oxford: Blackwell, p. 435.

Longo, M. (2003), 'European Integration: Between Micro-Regionalism and Globalism', JCMS, vol. 41 (3), pp. 34-217.

Maskell, P. and Malmberg, A. (1996), Proximity, institutions and learning. Towards an explanation of industry agglomeration and regional specialization. Paper presented at the NordREFO seminar: Regional Specialization and Local Environment - Learning and Competitiveness, Rungsted, 1996. 
Matlovič, R. and Matlovičová, K. (2005), 'Vývoj regionálnych disparít na Slovensku a problem regionálneho rozvoja Prešovského kraja' ['Development of regional disparities in Slovakia and problems of regional development in the Presov self-governing region'], Acta Facultatis Studiorum Humanitatis et Naturae Universitatis Presoviensis - Folia Geographica, vol. 8, pp. 66-88.

Michaeli E., Matlovič, R., Ištok, et al. (2010), Regionálny rozvoj pre geografov [Regional development for geographers]. Prešov, p. 717.

Murphy, A. (1991), 'Regions as Social Constructs: The Gap between Theory and Practice', Progress in Human Geography, vol. 14, pp. 22-35.

Paasi, A. (1986), 'The institutionalization of regions: a theoretical framework for understanding the emergence of regions and the constitution of regional identity', Fennia, vol. 164 (1), pp. 105-146.

Paasi, A. (1991), 'Deconstructing Regions: Notes on the Scales of Spatial Life', Environmental and Planning, vol. 23 (2), pp. 239-256.

Paasi, A. (2002), 'Place and Region: Regional Worlds and Words', Progress in Human Geography, vol. 26, pp. 802-811.

Paasi, A. (2003), 'Regional transformation in the European context: Notes on regions, boundaries and identity', Space and Polity, vol. 6 (2), pp. 197-201.

Piscová, M. (1996), Postoje a očakávania obyvatelov SR k integračným procesom a európskym Štruktúram [Attitudes and expectations of Slovakian citizens towards the European integration processes and structures]. Národná Identita - publikácia z výskumu. Bratislava: Sociologický ústav SAV, p. 93.

Raagmaa, G. (1999), 'Territorial identity as a competitive factor in regional economic development. Theme: Regional identities and governance: one Europe or several?', 1999, Draft of paper that was presented at the 39th ERSA Congress in August,. Dublin, Ireland, p. 49.

Relph, E. (1976), Place and Placelessness. London: Pion Ltd., p. 156.

Slavík, V. (2001), 'Najvýznamnejšie vedecké práce z oblasti hierarchizácie centier osídlenia, regionalizácie a analýzy medzisídelných väzieb’ [The most influential scientific works on the field of hierarchization settlement, regionalization and intraurban relationship], in: Alternatívny návrh usporiadania samosprávy vyššich územných celkov [Alternative territorial variants for self-governing regions in Slovakia], Bratislava, M.E.S.A. 10, pp. 34-44.

Sloboda, D. and Dostál, O. (2005), Župný variant 2005. Návrh na zmenu územného členenia SR [The selected variants of spatial division of Slovakia], Bratislava: Konzervatívny inštitút M. R. Štefánika, p. 19. 
Vondrušková, A., Od folklóru k folklorismu - Čechy. Slovník folklorního hnutív Čechách [From the folklore to folklorism in Czechia. The dictionary of folklore movement in Czechia]. Strážnice: NÚLK, 2000, p. 171.

Zemánek, L. (2003), 'Lokální kultura v životě našeho venkova' [Local culture and perception of life in the Czech countryside], in: Jančák, V., Chromý, P., and Marada, M. (ed.), Geografie na cestách poznání [Conference Proceedings: Geography of knowledge], Praha: Univerzita Karlova, PřF, Katedra sociální geografie a regionálního rozvoje, pp. 124-149.

Zich, F. (2003), 'Regionální identita obyvatel Euroregionu Nisa. Regionální identita obyvatel v pohraničí' [Regional identity of inhabitants in the Euroregion Neisse. Regional identity of inhabitants in the borderland], Sborník príspěvku $z$ konference "Evropská, národní, či regionální identita?" [Conference proceedings: European, national or regional identity?], Praha: Sociologický ústav Akademie věd ČR, pp. 17-59. 